\title{
How Accurate Are Measures of Long-Term Inflation Expectations?
}

\author{
Kevin L. Kliesen, Business Economist and Research Officer
}

$\mathbf{F}$ ederal Reserve policymakers regularly assess the probabilities of achieving their goals, including the goal of low and stable inflation. ${ }^{1}$ Modern theories posit that actual inflation depends importantly on expected future inflation. Hence, managing inflation expectations has a central role in the design and implementation of monetary policy.

That said, does it matter if current expectations for inflation over the next 5 years are wildly different from what actually occurs 5 years from now? For example, suppose policymakers in 2009 had expected inflation over the next 5 years to average 2 percent per year but it actually turned out to be 1 percent or 3 percent. Should policymakers care about the error in the forecasts? If the answer is that the forecast error matters, and that long-term inflation expectations are not very accurate, then policymakers may want to view today's long-term inflation expectations with a grain of salt. Let's assume that policymakers do care about their forecast errors and move on to investigating the accuracy of longterm inflation expectations at the time they are formed. ${ }^{2}$

\section{Inflation expectations formed in the mid-2000s weren't very accurate- in large part because of the shocks from the recession and financial crisis.}

Policymakers must grapple with a couple of related questions: which measure of inflation expectations to focus on and what time horizon to use. The current Monetary Policy Report to the Congress indicates that policymakers regularly examine several measures of inflation expectations, including the expectations of financial market participants, forecasts from staff economic models, the consensus of professional forecasters, and surveys of households and businesses. The horizon of these expectations matters because, over the shorter-term, actual inflation and inflation expectations can evolve in response to factors beyond monetary policy. Unexpected changes (shocks) in oil and food prices have often mattered the most. However, these types of nonmonetary shocks are temporary; over time, inflation is determined by monetary factors. ${ }^{3}$

The survey-based measure is the median response to a survey of households conducted by the University of Michigan Survey Research Center. The monthly survey asks consumers their expectations for CPI inflation over the next 5 to 10 years. The market-based measure is the difference between the nominal yield on U.S. Treasury securities and inflation-indexed Treasury securities of a comparable maturity, ${ }^{4}$ which is also known as the breakeven inflation rate (BEI). This essay uses the " 5 -year, 5-year forward" (5Y5Y) BEI, which measures the market's CPI inflation expectations for the 5 -year period beginning 5 years from now. ${ }^{5}$

One limitation of this analysis is that a consistent measure of inflation-indexed Treasury securities (constant maturity) has been around only since January 2003. So, we can compare actual inflation with market-based measures of long-term inflation expectations only over the past decade or so. The figure plots the two measures of longterm inflation expectations from January 2003 to December 2009. It also plots the actual annualized rate of change in the headline CPI over the period that encompasses the horizon of expected inflation. ${ }^{6}$ The difference between the two inflation expectations measures and the actual data at any point is the forecast error.

In January 2003, the Michigan survey reported that households expected inflation over the next 5 to 10 years to average 2.7 percent (median response). By contrast, the $5 Y 5 Y$ BEI indicated that financial markets expected CPI inflation to average 2.1 percent over this horizon. However, as seen in the figure, actual inflation was much less. In the figure, the actual inflation rate for January 2003 is the compounded annual rate of growth in the CPI that prevailed from January 2008 to July 2010. This horizon is assumed to be a reasonable approximation of the midpoint of the 


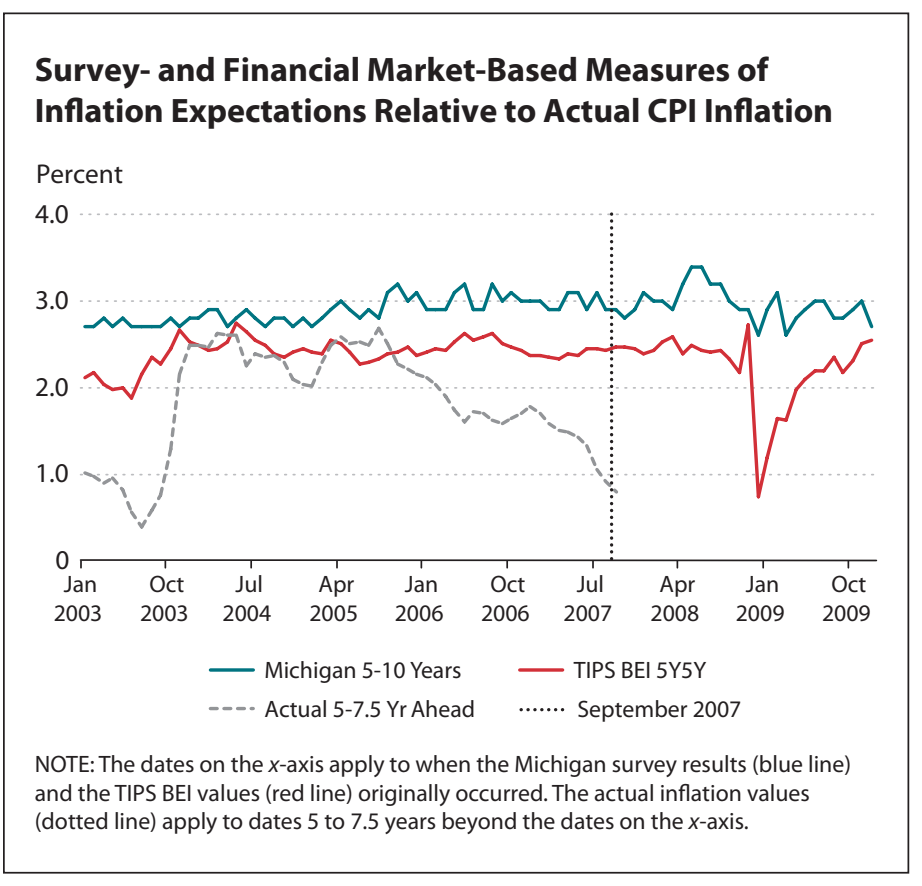

Sample Statistics and Forecast Accuracy for Inflation and Inflation Expectations

Sample Period: January 2003 to September 2007

Actual inflation horizon:

5 years to 7.5 years ahead

\begin{tabular}{lccc}
\cline { 2 - 4 } & Mich 5-10 & BEI 5Y5Y & Actual \\
\hline Mean & 2.89 & 2.40 & 1.81 \\
Standard deviation & 0.15 & 0.17 & 0.64 \\
RMSE & 1.25 & 0.82 & N/A
\end{tabular}

SOURCE: Author's calculations.
5- to 10-year horizon for the two measures of inflation expectations.

The figure reveals some interesting findings over this period: Households routinely overestimate CPI inflation, and market-based measures of inflation are invariably lower than household expectations. The table shows that the mean of the Michigan survey exceeds the BEI 5Y5Y by 49 basis points and actual inflation by a little more than 100 basis points ( 1 percentage point). Finally, market-based measures of inflation expectations are only slightly more volatile than household measures, based on standard deviation. However, both measures of inflation expectations are usually much less volatile than actual inflation.

To gauge the accuracy of long-term inflation expectations, the table shows the root mean squared error (RMSE) for each measure of inflation expectations. RMSEs are commonly used statistics to gauge the accuracy of forecasts. Market-based measures of inflation expectations (BEI 5Y5Y) are more accurate than household expectations: The RMSE of the BEI 5Y5Y (0.82 percent) was 34 percent more accurate than the household measure of inflation expectations (1.25 percent).

The evidence presented in this essay suggests that longerterm expectations of inflation that were formed in the mid2000 s were not very accurate. Indeed, actually inflation turned out to be significantly lower than expected-in large measure because of the shocks that occurred in the aftermath of the past recession and financial crisis. Going forward, most Federal Reserve officials expect inflation to eventually return to 2 percent. But when using measures of inflation expectations to forecast future inflation, policymakers and forecasters should focus on market-based measures of inflation expectations. They are much more accurate than survey-based measures. 


\section{Economic SYNOPSES}

\section{NOTES}

1 On January 25, 2012, the FOMC formally announced an inflation target: "the Committee judges that inflation at the rate of 2 percent, as measured by the annual change in the price index for personal consumption expenditures, is most consistent over the longer run with the Federal Reserve's statutory mandate."

2 Recent research by Trehan (2015) suggests that the accuracy of short-term headline inflation forecasts have deteriorated significantly over the past few years. Trehan (2015) examines 1-year-ahead CPI inflation forecasts published in the Federal Reserve Bank of Philadelphia's Survey of Professional Forecasters.

${ }^{3}$ Most market- and survey-based measures of inflation expectations are based on the future rate of change in the $\mathrm{CPI}$, whereas the FOMC aims to measure inflation benchmarked to the PCE price index (PCEPI). Over time, these inflation rates generally move together; but, because of different index methodologies and coverage, the CPI inflation rate tends to be a few tenths of a percentage point more than the PCEPI inflation rate over time.

${ }^{4}$ I ignore the risk premiums embedded in the nominal and real Treasury securities yields, such as liquidity and inflation risk.

5 The data for the BEl are from Haver Analytics, which calculates the implied 5 -year forward inflation rate using the implied 10-year BEl and the implied 5 -year BEl rates, which are the differences between the nominal security yield and the inflation-adjusted yield for the 10-year and 5-year constant maturity yields. For example, in January 2015, the 10-year BEl was 1.61 percent and the 5 -year BEl was 1.21 percent. The 5 Y 5 Y BEl is calculated as $\left[(1.0161)^{10} /(1.0121)^{5}\right]^{0.2}$ $=2.01$ percent.

6 Specifically, actual CPI inflation is measured as the 2.5 -year period that commences 5 years in the future (5 to 7.5 years). Admittedly, this is not an exact representation of the 5- to 10-year-ahead actual inflation rate. Rather, it is an approximation necessitated by the comparative lack of market-based inflation expectations data; the TIPS data used in the chart do not begin until January 2003.

\section{REFERENCE}

Trehan, Bharat. "Survey Measures of Expected Inflation and the Inflation Process," Journal of Money, Credit, and Banking, February 2015, 47(1), pp. 207-22. 